\title{
Multiple Accountability Relationships Matrix: A Hospital Setting
}

Harald Bergsteiner, Macquarie Graduate School of Management, Australia

Gayle C. Avery, (Email: Gayle.Avery@gsm.mq.edu.au), Macquarie Graduate School of Management, Australia

\begin{abstract}
Individuals, groups and organizations are subject to multiple accountability pressures that are often overlooked in analyzing accountability relationships. The shortcomings of two schemata for classifying and depicting multiple accountability relationships are addressed to create an alternative matrix-based approach. This matrix blends criteria espoused by category theorists with Bergsteiner's (2004) responsibility/accountability taxonomy. Although the proposed matrix is intended to generalize across accountability situations, its capacity to highlight one-way, mutual and self accountabilities of organizations and their many constituents in meeting their role/task, legal/ethical and moral responsibilities is demonstrated by focusing on accountability relationships affecting the operator of a privately operated hospital.
\end{abstract}

\section{INTRODUCTION}

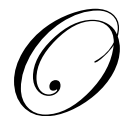

ne of the complexities in accountability theory is dealing with situations where people are accountable to more than one party, referred to as having multiple constituencies (Carnevale, 1985; Ferris, Mitchell, Canavan, Frink, \& Hopper 1995; Frink \& Klimoski, 1998; Katz \& Kahn, 1978; Leslie, Aring, \& Brand 1998; Shearer, 2002; Tsui, 1990). Clearly, most situations at home, work, or play (for example in competitive team sports) can give rise to multiple accountability relationships. In practice, accountability relationships can be very complex, particularly in large organizations.

At times different accountability relationships reflect conflicting interests, which has led some writers to conclude that the presumed diversity of goals of different constituencies makes it impossible for organizations to satisfy multiple constituencies simultaneously (e.g. Tsui, 1990). Other writers are more optimistic, arguing that by bringing the visions and goals of various parties into alignment, the interests of different constituencies can be satisfied (Avery, 2004; Leslie et al., 1998; Shearer, 2002). In order to achieve this goal alignment - or to recognize the interests among multiple constituencies that are not being satisfied - it is necessary to identify the affected parties and the nature of their accountability relationships. Despite the prevalence of multiple constituencies in accountability relationships, satisfactory ways of depicting and classifying relationships involving numerous parties have not been developed.

In this paper, we examine two existing schemata for classifying complex organizational accountability relationships, using criteria established by categorization theorists to identify some of their shortcomings. We then propose an Accountability Relationships Matrix to overcome the problems identified in the published schemata. A practical example of a hospital operator, for whom multiple accountability relationships arise, is used to demonstrate the utility of the Accountability Relationships Matrix.

\section{EXTANT SCHEMATA}

Romzek and Ingraham (2000) propose a matrix and a schema to depict the complexity of multiple accountability relationships in public organizations. Their two-by-two "types of accountability relationships" matrix aims to depict four kinds of accountability relationships thought to characterize U.S. public organizations hierarchical, legal, professional, and political. Each of the four accountability relationships in turn is classified 
according to whether the source of the accountability pressure is internal or external, and whether the degree of autonomy associated with a particular form of accountability is low or high.

Koppell (2005, p. 95) has suggested that "this approach seems to mix together types of accountability that are substantively different". Indeed, Romzek and Ingraham's (2000) matrix is comprised of a mix of elements that does not meet categorization criteria proposed by category theorists such as Britt (1997), Feigl (1988), Howard (1999), Klein (1999), or Rosch (1978). These theorists argue that members of a category should be one or more of the following: be organized into hierarchies of relative complexity, be subunits of a basic unit, form part of a structure or taxonomy, share common salient attributes, have category resemblance, or provide functional comparability. The four elements of Romzek and Ingraham's matrix do not meet this test because they variously describe a relationship typology (e.g. hierarchical, flat, networked, organic), prescriptions format (e.g. legal, moral, ethical, normative), skill level (e.g. professional, semi-professional, skilled, unskilled), and decision environment (e.g. political, philosophical, scientific, chance). Thus, each of their matrix elements could itself form the basis of a matrix.

The following example demonstrates the categorization quandary the Romzek and Ingraham (2000) matrix can pose in relation to specific situations. Legal professionals in, say, a politically tainted and hierarchically organized Attorney General's Department, theoretically fit any one of the four cells of the matrix (hierarchical, legal, professional, political). Similarly, doctors are clearly professionals, but they often work in hierarchically organized health systems such as hospitals. Romzek and Johnston (2005), in a more recent paper, appear to recognize this weakness when they write, "The stability offered by traditional hierarchical models of governance is lacking in the network systems that are increasingly being used to deliver social services" (p. 440). However, conceptually the Romzek and Ingraham (2000) matrix is limited to hierarchical accountabilities. Nor are any of the other potentially important accountabilities identified above, for example, nonprofessional and moral accountabilities, taken into consideration by either the matrix or the schema. As the hospitals case below shows, in order to be able to establish whether accountability relationships are working, one needs first to acknowledge that an accountability relationship exists and know the nature of that relationship.

The classificatory problems identified above may also account for problems at the contents level of the matrix. The four cells of Romzek and Ingraham's (2000) two-by-two matrix, which are stated to depict four kinds of accountability relationships, arguably do not represent relationships at all, but two equations and two unfeasible conditions.

In essence, Romzek and Ingraham's (2000) matrix advances the following four propositions with regard to the four types of accountability relationships:

1. Professional accountability relationship proposition: sources of expectations and/or control are internal, degree of autonomy is high. Since a person whose source of expectations is internal and who exercises internal control, by definition, would tend to have high autonomy, this proposition does not depict a relationship, but an equation, namely: internal control/expectations $=$ high autonomy.

2. Hierarchical accountability relationship proposition: sources of expectations and/or control are internal, degree of autonomy is low.

If the equation in 1. above holds (internal control/expectations = high autonomy), then the statement "internal control/expectations = low autonomy", as projected by the hierarchical, proposition cannot be true, that is: internal control/expectations $\neq$ low autonomy.

The hierarchical proposition therefore represents a logically impossible condition. Applying this to hierarchical, institutional settings, such as a hospital, employees lower down the hierarchy (e.g. nurses), by virtue of the hierarchical relationship, are subject to others' (e.g. managements') will and expectations (= external source). At each level of a hierarchy, the expectations and control reside in the next higher, and hence external, level. This example describes employees with low autonomy who are subject to external control/expectations. Note therefore that people can be subject to external expectations that have their source both within and outside the organization. For 
example, nurses and doctors may be subject to the requirements of their unions, professional associations, registration bodies, any public health authorities, and so on. Bovens (1998) sees the external control that characterizes hierarchical organizations as an institutionalized problem, where accountability demands may be satisfied through nothing more than compliance with a policy or a request from someone higher up the line.

3. Legal accountability relationship proposition: sources of expectations and/or control are external, degree of autonomy is low. A person whose source of expectations is external and who is subject to external control, by definition, would tend to have low autonomy, therefore this proposition also does not depict a relationship, but an equation, namely: external control/expectations = low autonomy.

4. Political accountability relationship proposition: sources of expectations and/or control are external, degree of autonomy is high. If the equation in 3. above holds (external control/expectations $=$ low autonomy), then the statement "external control/expectations = high autonomy', as projected by the political proposition cannot be true, that is: external control/expectations $\neq$ high autonomy.

Propositions 2 and 4 therefore represent logically inadmissible conditions. The matrix therefore fails in both its logic and in its classificatory approach.

In a separate schema, which builds on the matrix, Romzek and Ingraham (2000) propose an underlying "value emphasis" for the four kinds of accountability relationships (efficiency, rule of law, expertise, responsiveness), and the key "behavioral expectation" that is associated with each type of accountability relationship. In this schema the authors propose that the behavioral expectation associated with the hierarchical type of accountability is "obedience to organizational directives". This suggests a uni-directional accountability relationship. However, even in hierarchical organizations accountability works, or at least should work, in both directions (Bergsteiner, 2004; Frink \& Klimoski, 1998). Thus, hierarchy, per se, is not a useful differentiator for different types of accountability. The suggestion in the schema that the value emphasis of hierarchical structures is efficiency can also be challenged. More probably the value emphasis of hierarchical accountability is control and simplicity. While hierarchical structures have a certain simplicity when compared with matrix or networked structures (Mintzberg, 1993), whether this simplicity translates into efficiency depends on other variables, including the nature of the task. For example, a hierarchical structure may not be the most efficient for highly qualified, self-optimizing medical researchers since the kind of control that hierarchical structures tend to entail is not conducive to innovation, a certain degree of risk-taking, and organizational learning (Dose \& Klimoski, 1995; Gouldner, 1954; Müller \& Hurter, 1999).

The Romzek and Ingraham matrix and its associated schema therefore appear flawed in a number of respects: firstly in terms of their classificatory approach, and secondly in terms of some of the detailed implied argument.

Glynn and Perkins (1998) have proposed a second schema for classifying accountability relationships, which begins to reveal the wide range of accountabilities in a hospital system. In a comparative study of NSW and UK hospital systems, Glynn and Perkins identified six broad areas of accountability relationships:

1. professional disciplinary/occupational accountabilities

2. managerial accountabilities

3. inter-departmental accountabilities

4. purchaser accountabilities

5. financial/fiscal accountabilities

6. public/consumer accountabilities.

However, this list also raises similar issues to the Romzek and Ingraham tables. Even though it covers some important accountability categories, the Glynn and Perkins list is incomplete. Some missing accountability relationships for hospitals include supplier accountabilities, social and environmental accountabilities, nonprofessional/non-managerial accountabilities, intra-departmental accountabilities, corporate governance accountabilities, among others. Contrary to good category theory, the Glynn and Perkins model also mixes up 
category types such as entities (e.g. managerial accountability) with structural issues (e.g. interdepartmental accountability.)

In the specific case of a hospital operator trying to meet his/her role/task obligations in an organizational setting, the hospital director (representing the entity) will have a direct accountability relationship with a number of parties. These parties include doctors, nurses, patients, and the relevant government department(s), among others. Those parties themselves will have accountability relationships with each other (e.g. doctors and nurses, nurses and patients), that will impact indirectly on the ability of the accountee (the director) to meet role/task, legal/ethical and moral obligations. In this paper, we use the term 'accountor' to refer to the party that holds another party, the 'accountee', to account.

Therefore, while Romzek and Ingraham's chart and Glynn and Perkins' list go some way towards demonstrating the concept of multiple constituencies, as classification systems they lack completeness, structure and clarity (Britt, 1997; Feigl, 1988; Howard, 1999; Klein, 1999; Rosch, 1978). Given that people operating within a hierarchical, legal, professional, political, non-professional, financial/fiscal, artistic, ethical, managerial, procedural, familial, religious, or environmental context (the eclectic nature of this list is deliberate) are all subject to various degrees of role/task, legal/ethical and moral responsibility (Bergsteiner, 2004), it may be more instructive to look at accountability relationships through a conceptually less eclectic, framework that can be applied more generically. A framework incorporating these concepts is developed in the next section.

\section{ACCOUNTABILITY RELATIONSHIPS MATRIX}

Trying to quantify the multiplicity of mutual accountability relationships that need to be managed in an organization so that any one accountee or group of accountees can meet his/her/their obligations is challenging. The Accountability Relationships Matrix shown in Figure 1 adopts the responsibility/accountability concepts framework proposed by Bergsteiner and Avery (2003) to depict the multiplicity of accountability relationships potentially impacting on a privately run institution such as a hospital, prison, detention centre, nursing home or private school that is accountable to a government authority. Note that in the example presented here, the accountability focus is on the performance of the enterprise/institution, in this case a private hospital.

Concepts included in the matrix are defined elsewhere in detail (Bergsteiner, 2004; Bergsteiner \& Avery, 2003). However, role/task responsibility is essentially defined as a product of social roles that one acquires or chooses to accept, implying duties and obligations arising from the proper performance of the role and from group membership. Role/task responsibility, and concomitant accountability, is usually understood to be attached to particular tasks assigned to, or carried out by, people. Ethical/legal and moral responsibility derive from the requirement to make behavior, decisions and choices subject to legal, ethical and moral rules of conduct. Selfaccountability refers to behavior applied to the self, and involves self-evaluation of behavior and its consequence, and making voluntary changes to behavior (Dose \& Klimoski, 1995). Individuals may seek or self-administer rewards, sanctions or feedback based on progress towards goal attainment.

Entities at the left and the top of the matrix may play an accountor and/or accountee role with respect to the privately run institution. On the left, the entities are shown in their role as potential accountees; at the top, they are shown in their role as potential accountors. The various cells show whether there is a potential accountability relationship at all, whether this relationship is a mutual one or uni-directional, and the kind of obligations that relationship is based upon (role/task, legal/ethical and/or moral responsibility). Row 7 of Figure 1 indicates to whom the enterprise is accountable, and column $\mathrm{G}$ shows who is accountable to the enterprise. 
Figure 1: Accountability Relationships Matrix For A Private Hospital

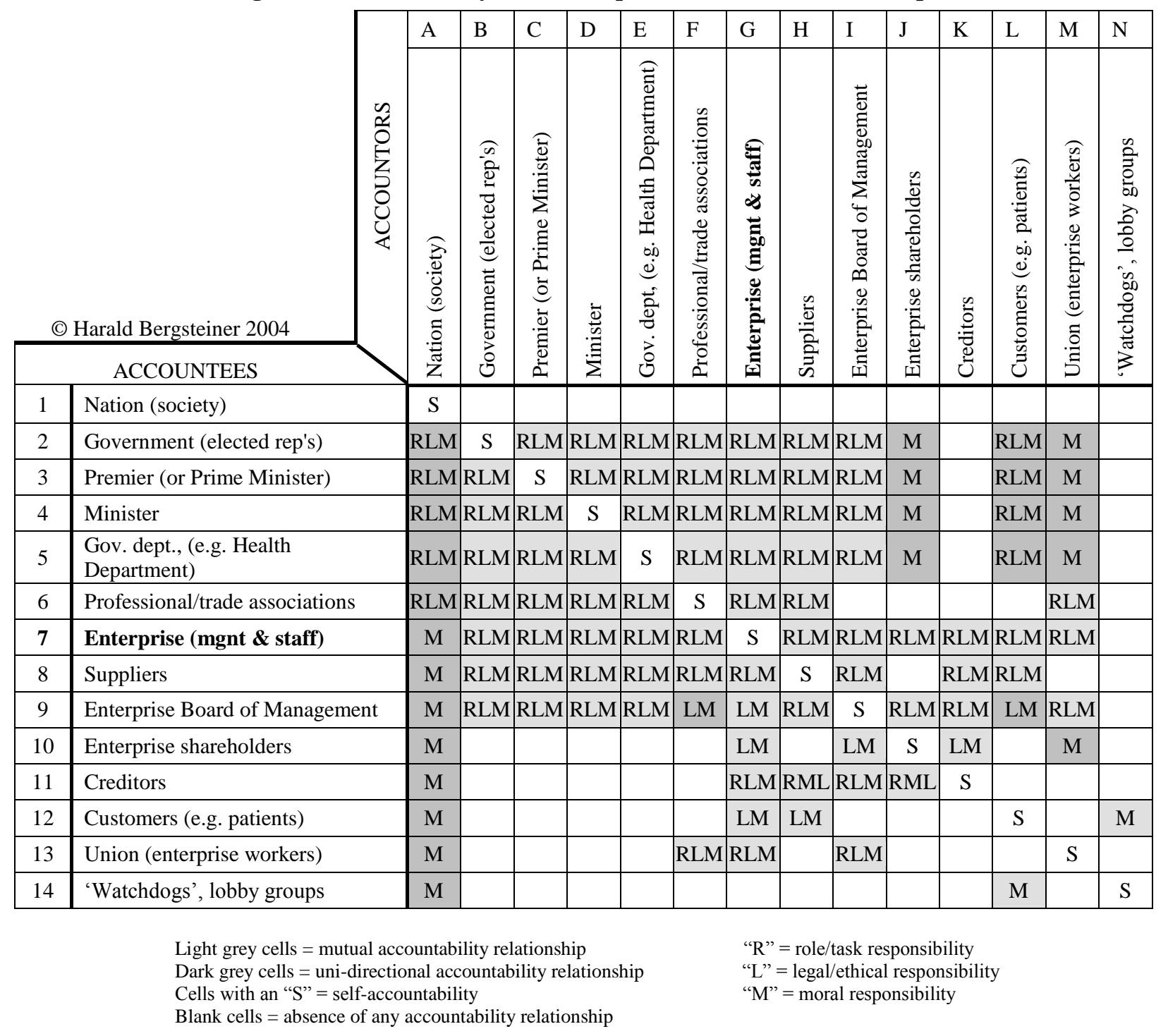

Figure 1 highlights seven different kinds of accountability relationships that impinge on the operator's ability to properly carry out his task: mutual accountability relationships (light grey cells) based on one or more of role/task, legal/ethical and moral responsibility; uni-directional accountability relationships (dark grey cells) based on one or more of role/task, legal/ethical and moral responsibility; and self-accountability (white cells with an "S").

The test of whether an entity should appear on this matrix or not is whether, with respect to the enterprises' operation, an entity has an obligation to the enterprise, or whether the enterprise has an obligation to the entity, that could give rise to an accountability demand. In the absence of any such obligations, accountability demands cannot arise (Bergsteiner, 2004). For example, in the case of a hospital operator, should the referring physicians appear on the matrix? If the referring physicians have no obligations to the private hospital operator regarding the running of the hospital, and since the hospital operator would normally have no obligations to the referring physicians as regards the running of the hospital, the referring physicians have no place on the matrix. On the other hand, the Health Department (the responsible government authority) has role/task and legal/ethical obligations to the relevant government minister to ensure that it establishes a legal and administrative framework for the operator that will allow 
him to properly carry out his responsibilities. Similarly, the Minister has obligations to the Health Department (e.g. to ensure that it is appropriately funded and supported). On the matrix, the two parties therefore appear as having mutual obligations with regard to the hospital's ability to carry out its obligations.

From Figure 1, it is evident that virtually any given situation can be depicted as a matrix of potential accountability relationships. Only those entities should be included on the matrix that are or may be in an accountability relationship with the party under examination. Thus, in Figure 1 the focus is on the "enterprise (management \& staff)". If the focus were on, say, the "government department", the content of the matrix would be somewhat different, since the government department would, under normal circumstances, not have an accountability relationship with, say, the creditors of the enterprise. On the other hand, the government department may have accountability relationships with other government departments or groups that impact on its ability to perform its function vis-à-vis the hospital enterprise. Thus, a matrix with different content needs to be generated for whichever entity is specifically being focused on.

Generating such a matrix for any accountee or group of accountees within a particular context is quite straightforward, by:

1. determining who the accountee is for a particular role/task;

2. listing all the actors who could be involved in an accountability relationship with that accountee in meeting his/her role/task obligations;

3. arranging the list of actors in a relevant sequence, e.g. in order of hierarchy if appropriate;

4. juxtaposing the two lists of actors/entities vis-à-vis each other in a matrix format;

5. highlighting pairings of actors at the intersection of matrix cells that may have an accountability relationship that impinges, either directly or indirectly, on the accountee's ability to properly perform his/her task; and

6. indicating the nature of the relationship, i.e. whether it is mutual or uni-directional, and which kinds of responsibility it is based on.

The proposed Accountability Relationships Matrix serves only to indicate broadly the large number of different types of accountability obligations and demands that can arise in any one situation. The accountability implications of each cell can generate considerable discussion and research. Certainly some of the accountability obligations and demands will be ongoing and immediate, whereas others will be more peripheral. For example, a hospital operator will have a direct, mutual and high-level accountability relationship with the relevant government department - the operator is required to fulfil his contractual obligations, and the government department is obliged to set up an operational framework that will enable the operator to properly discharge his responsibilities. Likewise, hospital patients stand in a mutual accountability relationship with the enterprise - the hospital is accountable for the quality of its care, but the patient has a legal and moral obligation to pay.

On the other hand, not all entrants in the matrix will have accountabilities to others. For example, societies tend not to owe others any explanations and are only rarely held accountable. Although every entity is responsible to society in one way or another, it is difficult to hold whole societies accountable except through such institutions as the United Nations or the International Court of Justice.

\section{CONCLUSION}

The generic Accountability Relationships Matrix proposed in this paper provides a template for highlighting the mutual, one-way and self accountabilities of organizations and their constituents in meeting their role/task, legal/ethical and moral responsibilities. The matrix overcomes problems identified in existing schemata for identifying multiple constituencies in accountability relationships. First, the matrix can be expanded to ensure completeness of the parties represented, just as it can be further refined internally. For a more fine-grained analysis, individual parameters such as the "enterprise" can be broken down into more discrete parts such as CEO, middle management or chief nurses. In terms of category theory, the parameters in the Accountability Relationships Matrix all represent entities/actors, and the cells all refer to responsibilities and obligations that these entities/actors hold with respect to 
each other. Thus, the template also fulfils category theorists' call for common salient attributes, category resemblance, and functional comparability.

\section{REFERENCES}

1. Avery, G. C. (2004). Understanding Leadership: Paradigms and Cases. London: Sage.

2. Bergsteiner, H., (2004). Modelling accountability complexity: A meta-theory. Unpublished PhD Thesis. Sydney: Macquarie Graduate School of Management.

3. Bergsteiner, H. \& Avery, G. C. (2003). Responsibility and accountability: Towards an integrative process model. International Business \& Economics Research Journal, Vol. 2, No. 2, 31-40.

4. Britt, D. W. (1997). A Conceptual Introduction to Modeling: Qualitative and Quantitative Perspectives. Mahwah, NJ: Lawrence Erlbaum.

5. Carnevale, P. J. D. (1985). Accountability of group representatives and intergroup relations. In E. J. Lawler (Ed.), Advance in Group Processes, Vol. 2. pp. 227-248. Greenwich, CT: JAI Press.

6. Dose, J. J. \& Klimoski, R. J. (1995). Doing the right thing in the workplace: Responsibility in the face of accountability. Employee Responsibilities and Rights Journal, Vol. 8, No. 1, 35-36.

7. Feigl, H. (1988). The scientific outlook: Naturalism and humanism. In E. D. Klemke, R. Hollinger, \& A. D. Kline (Eds.), Introductory Readings in the Philosophy of Science, pp. 427-437. Buffalo, NY: Prometheus Books.

8. Ferris, G. R., Mitchell, T. R., Canavan, P. J., Frink, D. D., \& Hopper, H. (1995). Accountability in human resources systems. In G. R. Ferris, S. D. Rosen \& D. T. Basman (Eds.), Handbook of Human Resource Management, pp. 175-196. Oxford: Blackwell Business.

9. Frink, D. D. \& Klimoski, R. J. (1998). Toward a theory of accountability in organizations and human resources management. Research in Personnel and Human Resources Management, Vol. 16, 1-51.

10. Glynn, J. \& Perkins, D. (1997). Control and accountability in the NHS market: A practical proposition or logical impossibility? International Journal of Public Sector Management, Vol. 10, No. 1/2, $62-75$.

11. Gouldner, A. W. (1954). Patterns of Industrial Bureaucracy. Glencoe, IL: Free Press.

12. Howard, R. W. (1999). Reconceptualizing learning. Review of General Psychology, Vol. 3, No. 4, 251263.

13. Katz, D. \& Kahn, R. L. (1978). The Social Psychology of Organizations (2 ${ }^{\text {nd }}$ ed.). New York: John Wiley.

14. Klein, H. (1999). Does modeling the real world in object oriented systems result in well-structured systems? Proceedings of $5^{\text {th }}$ International Conference, Decision Sciences Institute, Vol. II, pp. 1065-1069. Athens, Greece: New Technologies Publications.

15. Leslie, B., Aring, K. M., \& Brand, B. (1998). Informal learning: The new frontier of employee \& organizational development. Economic Development Review, Vol. 15, No. 4, 12.

16. Mintzberg, H. (1993). Structure in fives: Designing effective organizations. Englewood Cliffs, NJ: Prentice-Hall.

17. Müller, W. R. \& Hurter, M. (1999). Führung als Schlüssel zur organisationalen Lernfähigkeit. In G. Schreyögg \& J. Sydow, Managementforschung 9: Führung - neu gesehen. Berlin: DeGryter.

18. Romzek, B. S. \& Ingraham, P. W. (2000). Cross pressures of accountability: Initiative, command, and failure in the Ron Brown plane crash. Public Administration Review, Vol. 60, No. 3, 240-253.

19. Rosch, E. (1978). Principles of categorization. In E. Rosch \& B. B. Lloyd (Eds.), Cognition \& Categorization, pp. 27-48. Mahwah, NJ: Lawrence Erlbaum Associates.

20. Shearer, T. (2002). Ethics and accountability: From the for-itself to the for-the-other. Accounting, Organization and Society, Vol. 27, 541-573.

21. Tsui, A. S. (1990). A multiple-constituency model of effectiveness: An empirical examination at the human resource subunit level. Administrative Science Quarterly, Vol. 35, No. 3, 458-483. 


\section{NOTES}

